\title{
Senescence: General aspects about morphophysiology in the process of oral aging
}

\author{
Senescência: Aspectos gerais acerca da morfofisiologia no processo de envelhecimento oral \\ Senescencia: Aspectos generales acerca de la morfofisiología en el proceso de envejecimiento oral
}

Received: 04/20/2021 | Reviewed: 04/26/2021 | Accept: 05/19/2021 | Published: 06/04/2021

\author{
Julio Cesar Ramos Cadilho \\ ORCID: https://orcid.org/0000-0002-0897-2694 \\ Universidade do Grande Rio, Brazil \\ E-mail: juliocadilho@unigranrio.br \\ Nathana Reis Fraga Silva \\ ORCID: https://orcid.org/0000-0002-1473-0325 \\ Universidade do Grande Rio, Brazil \\ E-mail: nathanarf@gmail.com \\ Leone José da Silva Santos \\ ORCID: https://orcid.org/0000-0002-6616-1611 \\ Universidade do Grande Rio, Brazil \\ E-mail: leonepv@gmail.com \\ Rodrigo da Silva Oliveira Pinto \\ ORCID: https://orcid.org/0000-0002-7991-3966 \\ Universidade do Grande Rio, Brazil \\ E-mail: rodrigo2020ic@gmail.com \\ Hadassa de Almeida Almenara Rodrigues Amaro \\ ORCID: https://orcid.org/0000-0002-1812-463X \\ Universidade do Grande Rio, Brazil \\ E-mail: almenarahadassah@gmail.com \\ Silvia Maria Lyra \\ ORCID: https://orcid.org/0000-0002-7139-4698 \\ Universidade do Grande Rio, Brazil \\ E-mail: silviamcarv@gmail.com \\ Claudia Maria Pereira \\ ORCID: https://orcid.org/0000-0003-1280-6055 \\ Universidade do Grande Rio, Brazil \\ E-mail: claudemarie_br@unigranrio.edu.br
}

\begin{abstract}
Objective: This study aimed to perform an expository review about the aging process of oral tissues, correlating the information available in the literature to a conceptual and terminological view. For this purpose, a search was performed in the literature with reference to SCIELO, MEDLINE and Health Portals databases. Methods: The methodology used was the bibliographic, an explanatory research, combined with a contextualization of the data, where the main intention was to make science in the scope of qualitative methods and techniques of research. Where the inclusion criteria were availability of the full text of the study, to demonstrate clarity in the methodological detail used and to be available in Portuguese or English. Conclusion: Through the perquirition performed in this study, it was possible to discuss in an enriching way the proposed theme, encompassing several physiological aspects, morphological and external characteristic, while main actors in the process of Oral senescence.
\end{abstract}

Keywords: Senescence; Oral mucosa; Oral aging.

\section{Resumo}

Objetivo: Este estudo teve como objetivo realizar uma revisão expositiva sobre o processo de envelhecimento dos tecidos orais, correlacionando as informações disponíveis na literatura com uma visão conceitual e terminológica. Para isso, foi realizada busca na literatura com referência às bases de dados SCIELO, MEDLINE e Portais de Saúde. Métodos: A metodologia utilizada foi a bibliográfica, uma pesquisa explicatória combinada com uma contextualização dos dados, onde a intenção principal era fazer ciência no âmbito dos métodos qualitativos e técnicas de pesquisa. Onde os critérios de inclusão foram a disponibilidade do texto completo do estudo, para demonstrar clareza no detalhe metodológico utilizado e para estar disponível em português ou inglês. Conclusão: Através da perquirição realizada neste estudo, foi possível discutir de forma enriquecedora o tema proposto, englobando diversos aspectos fisiológicos, morfológicos e características externas, enquanto atores principais no processo de senescência oral.

Palavras-chave: Senescencia; Mucosa oral; Envelhecimento oral. 


\begin{abstract}
Resumen
Objetivo: Este estudio tuvo como objetivo realizar una revisión expositiva sobre el proceso de envejecimiento de los tejidos orales, correlacionando las informaciones disponibles en la literatura con una visión conceptual y terminológica. Para ello, se realizó búsqueda en la literatura con referencia a las bases de datos SCIELO, MEDLINE y Portales de Salud. Métodos: La metodología utilizada fue la bibliográfica, una investigación explicativa, combinada con una contextualización de los datos, donde la intención principal era hacer ciencia en el ámbito de los métodos cualitativos y técnicas de investigación. Donde los criterios de inclusión fueron la disponibilidad del texto completo del estudio, para demostrar claridad en el detalle metodológico utilizado y para estar disponible en portugués o inglés. Conclusión: A través de la investigación realizada en este estudio, fue posible discutir de forma enriquecedora el tema propuesto, englobando diversos aspectos fisiológicos, morfológicos y características externas, como actores principales en el proceso de senescencia oral.
\end{abstract}

Palabras clave: Senescencia; Mucosa oral; Envejecimiento oral.

\title{
1. Morphophysiology of the Oral Mucosa
}

The mucosa lining the buccal cavity is formed by stratified squamous epithelium, resembling the underlying connective tissue, called the lamina propria or corium. The epithelium acts as mechanical protection blockade and opposition to pathogen intrusion. Epithelial multiplication is limited to the basal layer that has resident stem cells, preserving their full self-renewal. Differentiated epithelial cells abandon contact with the basal membrane and find themselves displaced to the most superficial layers. This frequent renewal of the layers of the epithelium confers the integrity and barrier function of the oral mucosa (IglesiasBartolome et al., 2013)

This oral mucosa has an essential role closely related to the general health of the individual (Qin et al., 2017). With aging, there is a gradual and widespread decrease in the protective barrier function of the oral mucosa, the epithelium becomes less keratinized and consequent daily exposure of the host to pathogens and chemicals (Razak et al., 2014). The oral mucosa becomes more and more thin with age, also occurring the loss of its elasticity. With age, there is a tendency for the development of sublingual varicose veins, a decrease in wound healing rate and an increase in susceptibility to the development of various pathological conditions, such as Candida albicans infections (Papas et al., 1991).

Bone tissue, with aging, suffers a series of changes that cause decreased resilience to external and gradual forces and increased frailty due to loss of strength and hardness. The amount of mineralized, cortical, and medullary material is reduced by decreased turnover, resulting in bone porosity (Renvert \& Persson, 2016), as well as hormonal factors that are related to the bone tissue renewal process, estrogen, a hormone that is produced on a higher scale than in men, may be responsible for this increase in bone porosity, characterizing in more severe cases, osteoporosis, increasing the risk of fractures, for example. In addition, medicines and diseases of chronic character are most found in people of advanced and senile ages, such as dry mouth, gingival hyperplasia induced by drug use and inflammatory fibrous hyperplasia induced by mechanical trauma, such as use of poorly adapted prostheses, the loss of filiform papillae and even periodontal diseases installed with more significant characteristics (Renvert \& Persson, 2016).

\section{Senescence of the Oral Mucosa}

Over time, it is natural for the human body to undergo several morphological changes, which, many of them, affect the individual's oral health. Aging can be defined as a multifaceted natural process throughout the course of life, which is associated with a decline in physiological functions (Dwalibi et al., 2013). Since aging is a dynamic and progressive process, morphological, functional, and biochemical changes will occur in the body, being affected by several factors, such as lifestyle, environment, and genetics. (Chagas et al., 2012; Guiglia et al., 2010).

The senescence process is directly associated with morphological changes in the oral cavity. Differences related to age have been described, associated with the shape and number of epithelial cells, reduction in thickness, decrease in mitotic activity 
and proliferation of this tissue. Histological analysis of cheek mucosa of patients in different age groups, indicate that the epithelial cells of oral lining tend to be larger and more flattened with the passing of age, which could explain the apparent reduction in the thickness of the oral mucosa observed during aging (Abu Eid et al., 2011).

Darkened dental elements and root caries are manifestations of the effects of aging in the oral cavity (Freitas et al., 2006). It is also important to highlight the partial involvement of soft and bone tissues and tooth loss, with edentulism (loss of the dental element) being one of the most frequent oral impairments. Taste capacity changes due to the significant decrease of taste buds in the buds, especially the taste capacity of sweet, bitter salty and acid is impaired ${ }^{2}$ (Rosa et al., 2008, Silva et al., 2008b). An especially important characteristic is the considerable reduction of salivary flow, known as xerostomia. Xerostomia is a multifactorial condition, characterized by the subjective sensation of dry mouth resulting from the reduction of salivary flow, considerably increasing the risk of developing oral diseases and having an important effect on the overall quality of life of the individual. So, these patients need care for general and oral health maintenance (Kubbi et al., 2015). This saliva is more viscous, due to partial degeneration of the salivary glands, responsible for saliva secretion. With this strong decrease in salivary flow and increased viscosity, the elderly is prone to develop the process of caries disease, and still have difficulty digesting food that is due to the decrease in the production of salivary amylase, which may lead to significant nutritional deficiencies, with a nutritional index within the normal range but without nutrient absorption capacity (Rosa et al., 2008, Silva et al., 2008b).

\section{Bone Tissue and its Changes in Oral Aging}

Bone tissue is an organic system in constant remodeling, fruit of the formation processes, by osteoblasts, and reabsorption, by osteoclasts. In the first two decades of life, predominating the formation, there is a progressive increment of the bone mass (Sader; Rossi, 2002). In aging, there is a continuous bone loss throughout the human body, due to the activity of bone formation being infertile in relation to reabsorption. In this way, the jaws and the jaw suffer disuse atrophy (Sicher and Dubrul, 1975), this bone tissue suffers several changes and changes gradually, where there is loss of the factor resilience and resistance and starts to have a greater fragility, resulting from the significant decrease of mineralized tissue, occurring this process both in the cortical bone and in the trabecular portion. As stated earlier, the reabsorption activity is increased and the degree of bone formation is decreased, which may result in bone porosity (Marcaccini, et al 1997), in addition to the loss of support tissue for prostheses and implants, this bone loss can lead to temporomandibular dysfunctions, myofascial pain and a significant increase in the risk of fractures.

\section{Periodontium and the Process of Oral Aging}

Periodontitis is the form of highly destructive, that is most found in adults, where there is significantly increased risk of installing this condition with increasing age (Silva-Boghossian et al., 2009). Periodontal disease is directly influenced by several external factors, such as aging, smoking, inadequate oral hygiene, socioeconomic status, genetics, race, gender, obesity and diabetes mellitus and other systemic diseases (Nagpal et al., 2015). This pathological process constitutes a chronic inflammatory condition that is initiated by the accumulation of biofilm, where colonies of bacteria begin to release harmful substances to oral structures (Preshaw, 2019). The senectude process alters the inflammatory response to periodontal pathogens due to several factors, such as the increase in the formation of advanced glycation end products (Ages) and in the altered signaling and cell recruitment capacity (Salih and Brunet, 2008) where neutrophil cell types are more recruited than others. There is a destruction of tissues intended to contain the invasion by pathogens, it is mostly an exacerbated reaction.

Therefore, other biomolecular and cellular aspects are strongly involved in systemic, chronic, and low-intensity inflammation in aging explain the increased prevalence of PD in elderly individuals (Ebersole et al., 2016; Feres et al., 2016). 
With the advance of age, several degenerative diseases, systemic and cardiovascular problems end up being highlighted (Jardim, 2018). Periodontal diseases and cardiovascular diseases are closely linked, when studied more deeply, they share a number of risk factors that significantly increase the risk of these diseases such as smoking, alcohol intake, hypertension, generalized and daily stress, and diabetes (Vieira, 2014).

\subsection{Habits of Oral Hygiene}

Oral hygiene practices play an important role in the prevention of oral diseases, especially those of a periodontal nature (gingivitis and periodontitis). In a study with young people from southern Brazil, 77.8\% reported brushing their teeth > 3 times/day and $31.9 \%$ used dental floss (Freddo, 2008), this shows that the use of dental floss daily was not well accepted in the routine of young people, making a greater awareness campaign about this problem necessary. The use of dental floss is important because it is a mechanical factor capable of removing food debris of larger sizes in regions where the bristles of the toothbrush cannot reach. The interdental space is an important structure of retention of food debris and consequently biofilm formation, the floss acts in this place, partially cleaning the area so that the brush can arrive with the dentifrice and is made to sanitize the area.

Another study that was done compared the brushing habit in two moments of a municipality in southern Brazil; in 2011, $53.1 \%$ of individuals reported brushing their teeth at least once a day and $46.9 \%$ reported brushing twice or more times a day; and in $2015,61.5 \%$ reported brushing their teeth once a day, while $38.5 \%$ reported brushing their teeth twice or more times a day (Pauli, 2018). Since the 1970s, the epidemiological indexes of oral diseases more prevalent as caries began to decline significantly, mainly due to the increase of the mass dissemination of awareness of the importance of oral hygiene (MELO, 2001). Nevertheless, water fluoridation was also an important factor in this decrease in the incidence of caries, since fluoride ions are indispensable agents to the process of remineralization of dental elements, which with aging and external factors tend to decrease.

\section{Some Theories of Biological Aging}

\subsection{Endocrine Testing/ Glycosylation Theory}

This theory argues that the organism has biological times and that these times are capable of hormonal regulation, thus managing to control the speed of aging. Recent studies supporting this theory demonstrated that aging can be influenced by hormone levels and that the insulin-like growth factor (IGF) signaling pathway plays an important role in aging (van Heemst, 2010). The increase in longevity is due to the existence of mutations in this pathway that leads to the decrease of IGF, whose activation of the forkhead box $\mathrm{O}$ (Foxo) transcription factors that lead to the consumption of lipids instead of glucose, with the concomitant increase of the cellular resistance to stress, low-grade decreased inflammation, and increased mitochondrial biogenesis (Atwood \& Bowen, 2011; Liguori et al., 2018).

\subsection{Deoxyribonucleic Acid Repair Technique}

Deoxyribonucleic Acid (DNA) is the key to life. It is the genetic material that contains the crucial information for heredity, it is a determining factor in the phenotype of each living Being. This theory argues that aging is due to the cumulative process of aggression by the external environment. That is, as we age there is a decrease in the DNA repair capacity, this process leads, consequently, to an increase of successive errors at the level of deoxyribonucleic acid, thus generating several damages (Jin, 2010). The authors of this theory say that "the speed of DNA repair determines the time of life between species and between individuals of the same species". These conclusions were drawn after several studies carried out in which different cells of an organism have different DNA repair capabilities, concluding that it is related to aging and not the cause of it (Mota et al., 2004). 


\section{Oral Senescence and General Well-Being}

The full functionality of oral structures influences directly on the factor of well-being and quality of the individual. Since its total integrity is necessary for its proper functioning. The presence of all dental elements in the jaw and jaw strongly influences the well-being and self-image of the individual, a beautiful smile increases self-esteem. The smile proven to be an important aspect when it comes to the release of substances by the body of pleasure and full personal satisfaction.

With the oral senescence the individual, under several aspects of the most varied spheres, tends to lose dental elements, being this partial or total loss, but that has a great impact when we see the difficulty of expressing ourselves and being totally free to show feelings with joy, since this lack of teeth, if not answered with use of prostheses, in addition to causing damage to health, also brings aesthetic problems and decreases the quality of life of the individual. When asking for this dental support, and consequently the bone support, the lips tend to become flaccid and wrinkled, which causes these people to decrease social interaction and deprive themselves of social interactions that were once pleasurable.

\section{Conclusion}

The process of senescence in the oral cavity is associated with morphological changes in the oral mucosa, both in the number and shape of the cells. The morphological alterations of the oral cavity that are most present are dry mouth, reduced taste capacity, partial involvement of the periodontium, loss of dental elements and lesions in mucosa. The article also emphasized the importance of external factors as causal actors of aging processes of oral cavity structures. This is a sum of factors supporting such a process.

\section{References}

Abu Eid, R., Sawair, F., Landini, G. \& Saku, T. (2012). Age and the architecture of oral mucosa. Age, 34(3): 651-8

Atwood, C. S., \& Bowen, R. L. (2011). The reproductive-cell cycle theory of aging: An update. Experimental Gerontology, 46(2-3), $100-107$.

Chagas, A. M. \& Rocha, E. D. (2012). Aspectos fisiológicos do envelhecimento e contribuição da Odontologia na saúde do idoso. Rev. Bras. Odontol. 69(1): 94-6

Dwalibi, N. W., Anacleto, G. M. C., Witter, C., Goulart, R. M. M. \& Aquino, RC. (2013) Aging and quality of life: Analysis of scientific production in SciELo. Estudos de PsicologiaI Campinas 30(3): 393-403

Dye B. A. (2012) Global periodontal disease epidemiology. Periodontology 2000, 58(1): 10-25.

Ebersole J. L., Graves C. L., Gonzalez O. A., Dawson D., Morford L. A., Huja P. E., Hartsfield J. K. Jr., Huja S. S., Pandruvada S., \& Wallet S. M. (2016) Aging, inflammation, immunity, and periodontal disease. Periodontol 2000., 72(1):54-75.

Freitas, E.V. (2006) Tratado de geriatria e gerontologia. (2a ed.), Editora Guanabara, 1573.

Freddo, S. L., et al. (2008) Hábitos de higiene bucal e utilização de serviços odontológicos em escolares de uma cidade da Região Sul do Brasil. Cad. Saúde Pública, 24(9): 1991-2000.

Grénman R., Chevalier D., Gregoire V., Myers E., \& Rogers S. Treatment of head and neck cancer in the elderly: European Consensus (panel 6) at the EUFOS Congress in Vienna 2007. Eur Arch Otorhinolaryngol., 267(10):1619-21

Guiglia R., Musciotto A., Compilato D., Procaccini M., Lo Russo L., Ciavarella D., Lo Muzio L., Cannone V., Pepe I, D'Angelo M., \& Campisi G. (2010) Aging and oral health:effects in hard and soft tissues. Curr Pharm Des. 2010, 16(6):619-30.

Iglesias-Bartolome R., Callejas-Valera J. L., \& Gutkind J. S. (2013) Control of the epithelial stem cell epigenome: the shaping of epithelial stem cell identity. Curr Opin Cell Biol. Apr, 25(2):162-9.

Jardim P. C. B. V. (2018) A SBC e a Hipertensão Arterial: é hora de ação. Arq Bras Cardiol., 111(3):343-344

Jin, K. (2010). Modern Biological Theories of Aging. Aging and Disease, 1(2), 72-74.

Kubbi J. R., Reddy L. R., Duggi L. S., \& Aitha H. Xerostomia: An overview. J Indian Acad Oral Med Radiol. 27:85-89.

Liguori, I., Russo, G., Curcio, F., Bulli, G., Aran, L., Della-Morte, D., \& Abete, P. (2018). Oxidative stress, aging, and diseases. Clinical Interventions in Aging, 13, 757-772. 
Marcaccini, A. M., Souza, P. H. R, \& Toledo, B. E. G. (1997) A influencia da idade sobre o periodonto. Odonto 2000 - Odontologia do Século XXI, 1(1), 8 12 ,

Mota, M. P., Figueiredo, P. A., \& Duarte, J. A. (2004). Teorias biológicas do envelhecimento. Revista Portuguesa de Ciências Do Desporto(1), 81-110.

Moura E. C., \& Malta D. C. (2011) Consumo de bebidas alcoólicas na população adulta brasileira: características sociodemográficas e tendência. Rev Bras Epidemiol, 14(1): 61-70.

Melo, N. S. F. O., Seto E. P. S, \& Germann E. R. (2001) Medidas de higiene oral empregadas por pacientes da terceira idade. Pesq Bras Odontopediatria Clin Integr, 1(3):42-50.

Nazir M. (2017) Prevalence of periodontal disease, its association with system diseases and prevention. Int J Health SciEduc,11(2):72-80.

Nagpal R., Yamashiro Y., \& Izumi, Y. (2015) The Two-Way Association of Periodontal Infection with Systemic Disorders: An Overview. Mediators of Inflammation, 1-9.

Papas A. S., Niessen L. C., \& Chauncey H. H. (1991) Geriatric Dentistry - Aging and Oral Health. Mosby Yearbook.

Preshaw, P. M., \& Bissett S. M. (2019) Periodontitis and diabetes. British Dental Journal, 227(7): 577-584.

Pauli T. P et al. (2018) Saúde bucal de idosos com 80 anos ou mais: condição, autopercepção e utilização de serviços odontológicos. Rev. odontol. UNESP, 47(5): 291-297.

Pesquero, A..C. B. (2005) Uso de prótese dentária total por idosos: aspectos psicológicos. [Dissertação de Mestrado]. Goiânia: Universidade Católica de Goiás,. 56p.

Qin, R., Steel, A., \& Fazel, N. (2017) Oral mucosa biology and salivary biomarkers. Clinics in Dermatology, 35(5): $477-483$.

Razak P. A., Richard K. M., Thankachan, R. P., Hafiz, K. A., Kumar, K. N., \& Sameer, K. M. (2014) Geriatric oral health: a review article. J Int Oral Health, 6:110-116.

Renvert, S., \& Persson, R. G.( 2016) Treatment of periodontal disease in older adults. Periodontology 2000,72: 108-119

Rosa, L. B., Zuccolotto, M. C. C., Bataglion, C., \& Coronatto, E. A. S. (2008) Odontogeriatria - a saúde bucal na terceira idade. RFO UPF, 13(2):82-6,

Rossi, E., \& Sader, C. S. Envelhecimento do sistema osteoarticular. In: Freitas EV, Py L., Cançado FAX, Doll J., Gorzoni M.L. (2006) Tratado de Geriatria e erontologia (2a ed.), Guanabara Koogan.792-7.

Silva, S. O., Trentin, M. S., Linden, M. S. S., Carli, J. P., Silveira Neto, N., \& Luft L. R. (2008) Saúde bucal do idoso institucionalizado em dois asilos de Passo Fundo - RS. RGO 56(3):303-8.

Shenoy, N., Sholapurkar, A. A., Pai, K. M., \& Adhikari, P..(2010) Oral health status in geriatric diabetics. Rev Clín Pesq Odontol., 6(1):63-9.

Salih, D. A., \& Brunet, A. (2008) FoxO transcription factors in the maintenance of cellular homeostasis during aging. Curr Opin Cell Biol, 20(2):126-36.

Silva, S. T. da et al. (2014) Combate ao Tabagismo no Brasil: a importância estratégica das ações governamentais. Ciência \& Saúde Coletiva, 19(2).

Sicher, H., \& Dubrul, E. L. (1975) Oral anatomy. Guanabara Koogan.

Silva-Boghossian, C. M., Luiz, R. R., \& Colombo, A. P. (2009) Periodontal status, sociodemographic, and behavioral indicators in subjects attending a public dental school in Brazil: analysis of clinical attachment loss. J Periodontol, 80(12): 1945-54.

Vieira, R. W. (2014) Cardiovascular and periodontal diseases. Revista Brasileira de Cirurgia Cardiovascular, 29(1): 7-9.

van Heemst, D.. (2010). Insulin, IGF-1 and longevity. Aging and Disease, 1(2), 147-157. 